\title{
Wedge-Shaped Growth Pattern
}

National Cancer Institute

\section{Source}

National Cancer Institute. Wedge-Shaped Growth Pattern. NCI Thesaurus. Code C62464.

A morphologic architectural pattern in which the tumor cells spread in a wedge-shaped pattern. 